about six times its value on the 1936 distance scale; the Hubble constant of recession would be $87 \mathrm{~km} . / \mathrm{sec} . /$ megaparsec. A similar result follows from studies of the globular clusters in the nebula $M 87$. These arguments do not constitute a rediscussion of the distance scale. Precise new measurements are required for this, and such measurements are now in progress at Mount Palomar.

Atoms for Peace Conference : American Publication

AT the second International Conference on the Peaceful Uses of Atomic Energy recently held in Geneva, a set of twelve volumes dealing with the American participation, written expressly for the Conference and containing much information just declassified, was presented to official delegates as a gift from the United States. These volumes have now been published by Addison-Wesley Publishing Co., Inc., Reading, Mass., on behalf of the U.S. Atomic Energy Commission. (The volumes are also obtainable from Academic Books, Ltd., 129, Queensway, London, W.2.) The price of each separate volume varies from $45 s$. $6 d$. to $92 s$. ; but the complete set is available at $£ 30$. Further information can be obtained from either the Addison-Wesley Publishing Co., Inc., or Academic Books, Ltd., at the above addresses.

\section{Mammal Society of the British Isles}

A symposium entitled "Mammals in British History and Prehistory" will be held in the meeting room of the Zoological Society of London, Regent's Park, on November 1. Non-members of the Society are invited to attend; there is no registration fee. The programme will include talks on the conditions for the preservation of mammalian remains, and blood grouping of human remains; the mammalian fauna and environmental conditions at the close of the Pleistocene; the mammalian fauna from Star Carr ; and the historical development of farm animals in relation to their environment. Further details can be obtained from the conference secretary, Dr. K. M. Backhouse, Charing Cross Hospital Medical School, 62-65 Chandos Place, London, W.C.2.

\section{Torry Research Station}

THe Council for Scientific and Industrial Research announces that responsibility for the research programme of the Torry Research Station at Aberdeen will be vested in a steering committee, consisting of : Dr. B. K. Blount (chairman), deputy secretary of the Department of Scientific and Industrial Research; Mr. G. C. Wilson, a member of the White Fish Authority and the Herring Industry Board; Dr. D. Traill, director of research of the Nobel Division of Imperial Chemical Industries at Stevenston, Ayrshire; Mr. H. Wooldridge, head of the Stations Division of Headquarters, Department of Scientific and Industrial Research; and the director of the Station, Dr. G. A. Reay. Dr. Reay's title was formerly 'superintendent', but it has now been changed to 'director'.

\section{Announcements}

Mr. J. Wiuson has been awarded the Hinchley Medal of the British Association of Chemists for 1957. The formal presentation will be made at the Royal Society of Medicine (West Hall), 1 Wimpole Street, London, W.1, on October 29, at 7 p.m. Mr. Wilson will then deliver the Hinchley Memorial Address, which is entitled "Grant-aided Research Associations".
Mr. Alec M. Hughes, general secretary of the Scientific Film Association, has been appointed visual aids officer of the British Association for the Advancement of Science.

Mr. A. P. Gagnebin, who has been elected a vicepresident of the International Nickel Company, Inc., joined the Company's research laboratory at Bayonne, New Jersey, in 1932 and devoted himself to research on ferrous metals. He became a member of the Ductile Iron Section of the International Nickel Company's Development and Research Division in 1949 , where he was active in the industrial development of ductile iron, of which he is a co-inventor. In May 1952, Mr. Gagnebin was a co-recipient of the Peter L. Simpson Gold Medal of the American Foundrymen's Society, for outstanding work and development in the field of ductile iron. $\mathrm{He}$ is the author of many technical papers and of the book, "The Fundamentals of Iron and Steel Castings".

THE British Council (65 Davies Street, London, W.1; telephone, Grosvenor 8011) asks senior academic scientists who are contemplating overseas tours (other than to the United States) to inform it of their intentions. The Council can often help with specialist contacts-and can sometimes arrange lectures by the traveller-in the countries to be visited or en route. Such collaboration is greatly valued by the Council as an important contribution to its efforts to promote a wider knowledge overseas of the sciences in Britain. Communications on this subject can be addressed to the Director, Specialist Tours Department.

THE winter conference of the Physical Society, on physics of the solid state, will be held in the Cavendish Laboratory, Cambridge, during December 18-20. The subject of the conference will be interfacial phenomena, and it is hoped that papers will be given on some or all of the following subjects : (1) structure of vacuum-evaporated layers on single-crystal substrates; (2) structure of electrodeposited layers; (3) epitaxy ; orientation of crystals on various substrates; (4) grain boundary phenomena; the interface between different phases in metals; (5) the interface between solid and liquid phases. Those wishing to take part are invited to write to Prof. N. F. Mott, Cavendish Laboratory, Cambridge.

The fourth Congress on Theoretical and Applied Mechanics will be held under the presidentship of Dr. S. R. Sen Gupta at the Bengal Engineering College, Howrah, Calcutta, during December 28-31. Research papers may be contributed on any of the following topics: (1) elasticity, plasticity, rheology ; (2) fluid mechanics (aerodynamics, hydrodynamics); (3) mechanics of solids (ballistics, vibrations, frictionlubrication); (4) statistical mechanics, thermodynamics, heat transfer ; (5) mathematics of physics and mechanics; and (6) experimental techniques. Registration forms and further information can be obtained from the Secretary-Treasurer, Indian Society of Theoretical and Applied Mechanies, Indian Institute of Technology, Kahragpur, India.

Erratum. Reference was made in the article entitled "Academic and Professional Mobility" in Nature of August 16, p. 413, to a paper by Dr. P. E. Weatherley; we regret that his name was wrongly spelled in that article and also in an earlier article (Nature, 181, 677 ; 1958). 